\title{
Characterizations of Cuprous Oxide Thin Films Prepared by Sol-Gel Spin Coating Technique with Different Additives for the Photoelectrochemical Solar Cell
}

\author{
D. S. C. Halin, ${ }^{1}$ I. A. Talib, ${ }^{2}$ A. R. Daud, ${ }^{2}$ and M. A. A. Hamid ${ }^{2}$ \\ ${ }^{1}$ Center of Excellence Geopolymer \& Green Technology (CEGeoGTech), School of Materials Engineering, \\ Universiti Malaysia Perlis (UniMAP), Jalan Kangar-Arau, 02600 Perlis, Malaysia \\ ${ }^{2}$ School of Applied Physics, Faculty of Science and Technology, Universiti Kebangsaan Malaysia(UKM), \\ 43600 Bangi, Selangor, Malaysia
}

Correspondence should be addressed to D. S. C. Halin; dewisuriyani@unimap.edu.my

Received 10 December 2013; Revised 16 April 2014; Accepted 14 May 2014; Published 15 June 2014

Academic Editor: Prakash Basnyat

Copyright (C) 2014 D. S. C. Halin et al. This is an open access article distributed under the Creative Commons Attribution License, which permits unrestricted use, distribution, and reproduction in any medium, provided the original work is properly cited.

\begin{abstract}
Cuprous oxide $\left(\mathrm{Cu}_{2} \mathrm{O}\right)$ thin films were deposited onto indium tin oxide (ITO) coated glass substrate by sol-gel spin coating technique using different additives, namely, polyethylene glycol and ethylene glycol. It was found that the organic additives added had a significant influence on the formation of $\mathrm{Cu}_{2} \mathrm{O}$ films and lead to different microstructures and optical properties. The films were characterized by X-ray diffraction (XRD), field emission scanning electron microscopy (FESEM), and ultraviolet-visible spectroscopy (UV-Vis). Based on the FESEM micrographs, the grain size of film prepared using polyethylene glycol additive has smaller grains of about $83 \mathrm{~nm}$ with irregular shapes. The highest optical absorbance film was obtained by the addition of polyethylene glycol. The $\mathrm{Cu}_{2} \mathrm{O}$ thin films were used as a working electrode in the application of photoelectrochemical solar cell (PESC).
\end{abstract}

\section{Introduction}

Cuprous oxide $\left(\mathrm{Cu}_{2} \mathrm{O}\right)$ has a cubic crystal structure with a lattice parameter of $4.27 \AA$ and this material is suitable for solar cell applications. As a solar cell material, $\mathrm{Cu}_{2} \mathrm{O}$ has the advantages of low cost and great availability [1]. The $\mathrm{Cu}_{2} \mathrm{O}$ is very attractive as a photovoltaic material because of its high absorption coefficient in visible regions, nontoxicity, abundantly available starting material $(\mathrm{Cu})$ on earth, low cost to produce, and the theoretical energy conversion efficiency being in the order of $20 \%$ [2]. $\mathrm{Cu}_{2} \mathrm{O}$ thin films can be prepared by various methods like reactive sputtering [3, 4], vacuum evaporation [5], chemical and thermal oxidation $[6,7]$, and electrodeposition $[8,9]$. In recent times, solgel technique has proved to be an attractive method for the preparation of nanoscale grain size of metal and metal oxide materials. Armelao et al. [10] used sol-gel dip coating technique to prepare $\mathrm{Cu}_{2} \mathrm{O}$ film with copper acetate and ethanol without any additive. Oral et al. [11] prepared $\mathrm{CuO}$ films with copper acetate and isopropyl alcohol and the additives used were polyethylene glycol 400 and ethylene glycol. In this research, $\mathrm{Cu}_{2} \mathrm{O}$ thin film was deposited onto indium tin oxide (ITO) coated glass using sol-gel technique with two different polymer additives such as polyethylene glycol and ethylene glycol because it is a soft bottom-up approach to achieve a good control over film composition and microstructure.

Investigations had shown that some polymer additives, such as polyethylene glycol $\left(\left(\mathrm{CH}_{2}-\mathrm{CH}_{2}-\mathrm{O}\right)_{n}-\mathrm{H}\right)$, effectively improve the $\mathrm{Cu}_{2} \mathrm{O}$ properties under relatively low temperature $[12,13]$. To our knowledge, the use of additives is seldom found in $\mathrm{Cu}_{2} \mathrm{O}$ preparation. The purpose of this research is to prepare $\mathrm{Cu}_{2} \mathrm{O}$ thin film onto indium tin oxide (ITO) coated glass substrate for photoelectrochemical solar cell application (PESC) by means of sol-gel spin coating technique and to investigate the behavior of $\mathrm{Cu}_{2} \mathrm{O}$ thin films under different additives. Not many researchers have used polyethylene glycol and ethylene glycol as additives in sol-gel technique. The as-prepared films were annealed at $350^{\circ} \mathrm{C}$ in $5 \% \mathrm{H}_{2}+95 \% \mathrm{~N}_{2}$ atmosphere in order to get single 
phase $\mathrm{Cu}_{2} \mathrm{O}$ films. The annealing temperature of $350^{\circ} \mathrm{C}$ is the optimum annealing temperature to prepare the single phase $\mathrm{Cu}_{2} \mathrm{O}$ films. If the annealing temperature is increased to $450^{\circ} \mathrm{C}$, other phases exist such as $\mathrm{Cu}$ or $\mathrm{CuO}$ comes into existence. The prepared $\mathrm{Cu}_{2} \mathrm{O}$ thin film was used as a working electrode for PESC of ITO/ $\mathrm{Cu}_{2} \mathrm{O} / \mathrm{PVC}-\mathrm{LiClO}_{4} /$ aluminum. PESC based on $\mathrm{Cu}_{2} \mathrm{O}$ thin films were fabricated and the current-voltage characteristic of PESC of ITO/ $\mathrm{Cu}_{2} \mathrm{O} / \mathrm{PVC}$ $\mathrm{LiClO}_{4} /$ aluminum was studied under light illumination of $100 \mathrm{~mW} / \mathrm{cm}^{2}$.

\section{Experimental}

Copper (II) acetate $\left(\mathrm{Cu}\left(\mathrm{C}_{2} \mathrm{H}_{3} \mathrm{O}_{2}\right)\right.$, $99.999 \%$ purity) was used as starting material for the synthesis of cuprous oxide thin films. Copper (II) acetate was dissolved in isopropyl alcohol and diethanolamine $\left(\mathrm{DEA}, \mathrm{C}_{4} \mathrm{H}_{11} \mathrm{NO}_{2}\right)$ solution and mixed continuously. Small amount of glucopon was then added into the solution and continuously stirred for 24 hours using magnetic bar. The solution was then filtered using $0.45 \mu \mathrm{m}$ filter prior to spinning. Films were prepared by depositing the solution by spin coating technique onto indium tin oxide (ITO) coated glass substrate which was purchased from Sigma-Aldrich. The solution was spread onto the substrate at $3000 \mathrm{rpm}$ for $40 \mathrm{~s}$. The films were dried in the oven at $60^{\circ} \mathrm{C}$ for $10 \mathrm{~min}$ and the process was repeated for three layers of coating in order to get better films which fully covered the substrate. Two different additives were used, that is, polyethylene glycol and ethylene glycol. There were three sets of samples: (a) sample 1 (sample without any additive), (b) sample 2 (sample with polyethylene glycol), and (c) sample 3 (sample with ethylene glycol). Films were annealed at $350^{\circ} \mathrm{C}$ for $1 \mathrm{~h}$ in $5 \% \mathrm{H}_{2}+95 \% \mathrm{~N}_{2}$ atmosphere. The use of $5 \% \mathrm{H}_{2}+95 \% \mathrm{~N}_{2}$ atmosphere during annealing because of $\mathrm{H}_{2}$ strongly affects the phase composition of $\mathrm{Cu}_{2} \mathrm{O}$ thin film. Without the atmosphere of $5 \% \mathrm{H}_{2}+95 \% \mathrm{~N}_{2}$, the phase composition may not be a single phase of $\mathrm{Cu}_{2} \mathrm{O}$ thin films because there is more oxygen for copper oxide to form $\mathrm{CuO}$ rather than $\mathrm{Cu}_{2} \mathrm{O}$. The microstructure of the films was studied using X-ray diffractometer (XRD) model D-5000 Siemens. The morphology of the film was observed using field emission scanning electron microscope (FESEM) model Supra 55VP and optical properties were measured using ultraviolet-visible (UV-Vis) spectroscopy model 160A Shimadzu in the range of $300-900 \mathrm{~nm}$.

\section{Results and Discussion}

The XRD patterns of obtained samples with different additives are shown in Figure 1. All diffraction peaks can be indexed to the cubic phase of $\mathrm{Cu}_{2} \mathrm{O}$ crystals and match well with standard data (JCPDS 74-1230). No other phases such as $\mathrm{CuO}$ or $\mathrm{Cu}$ are found in XRD patterns confirming that all the samples exist as main $\mathrm{Cu}_{2} \mathrm{O}$ phase. The presence of (110) plane may be due to the mechanism of the thin film which was oxidized to $\mathrm{Cu}_{2} \mathrm{O}$. In the sol-gel technique, the temperature and time are important factors. The single phase of $\mathrm{Cu}_{2} \mathrm{O}$ thin films can be prepared at temperature of $350^{\circ} \mathrm{C}$ and time of annealing of 1 hour. When the temperature is lower or the

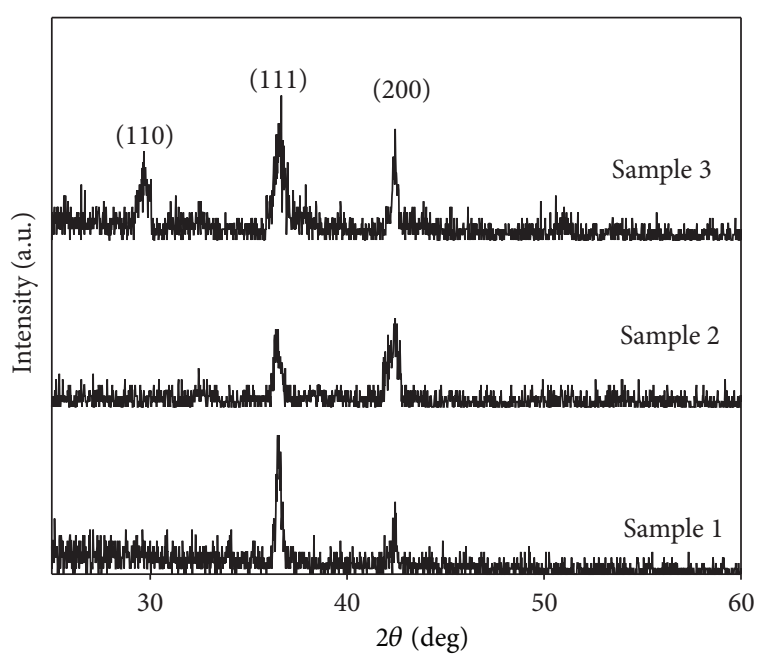

FIGURE 1: The XRD patterns of cuprous oxide thin films with different additives.

TABLE 1: The energy gap, grain size, thickness, and plane $(h k l)$ of the $\mathrm{Cu}_{2} \mathrm{O}$ films.

\begin{tabular}{lcccc}
\hline Samples & $\begin{array}{c}\text { Energy gap } \\
(\mathrm{eV})\end{array}$ & $\begin{array}{c}\text { Grain size } \\
(\mathrm{nm})\end{array}$ & $\begin{array}{c}\text { Thickness } \\
(\mathrm{nm})\end{array}$ & $\begin{array}{c}\text { Plane } \\
(h k l)\end{array}$ \\
\hline 1 & $1.85 \pm 0.1$ & 104 & 102 & $(111),(200)$ \\
2 & $1.90 \pm 0.1$ & 83 & 395 & $(111),(200)$ \\
3 & $1.75 \pm 0.1$ & 90 & 59 & $(110),(111),(200)$ \\
\hline
\end{tabular}

time is shorter, it is hard to reduce cupric acetate to cuprous oxide completely, whereas if the temperature is too high or the reaction time is too long, it is easy to get copper rather than cuprous oxide [14].

Figure 2 shows the FESEM micrographs of three set of samples which shows that the films grown on ITO substrate are uniform. The average grain size and thickness of the $\mathrm{Cu}_{2} \mathrm{O}$ films for the samples are shown in Table 1 . The cross section of thin films was used to measure the thickness of the film while the grain size was measured from the FESEM micrograph. The grain size was reducing from $104 \mathrm{~nm}$ to $83 \mathrm{~nm}$, after adding polyethylene glycol. The thickness of thin film increased with the addition of polyethylene glycol. It is shown that the addition of polyethylene glycol will increase the viscosity of solution due to chain length effects [13]. The spin coating rate also can affect the thickness of the thin film; lower spin coating rate produce much thicker film due to less solution spread out from substrate.

The addition of ethylene glycol has been widely used in the polyol synthesis of metal and metal oxide due to its strong reducing ability and relatively high boiling point $\left(\sim 197^{\circ} \mathrm{C}\right)$. Polyol synthesis of metal consists in the reduction of metal cation in a polyol medium. Over the past few years, polyols have also been used to elaborate a great variety of oxides $[15,16]$ and layered hydroxyl-salt [17] by means of hydrolysis and inorganic polymerization. The addition of ethylene glycol (sample 3) with thickness of $59 \mathrm{~nm}$ shows that the $\mathrm{Cu}_{2} \mathrm{O}$ grains were irregular in shape. 


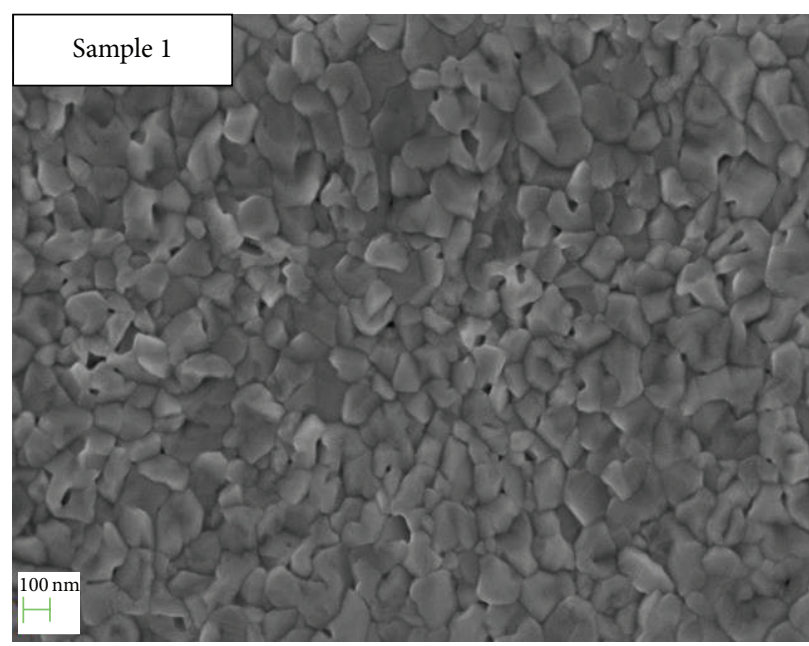

(a)

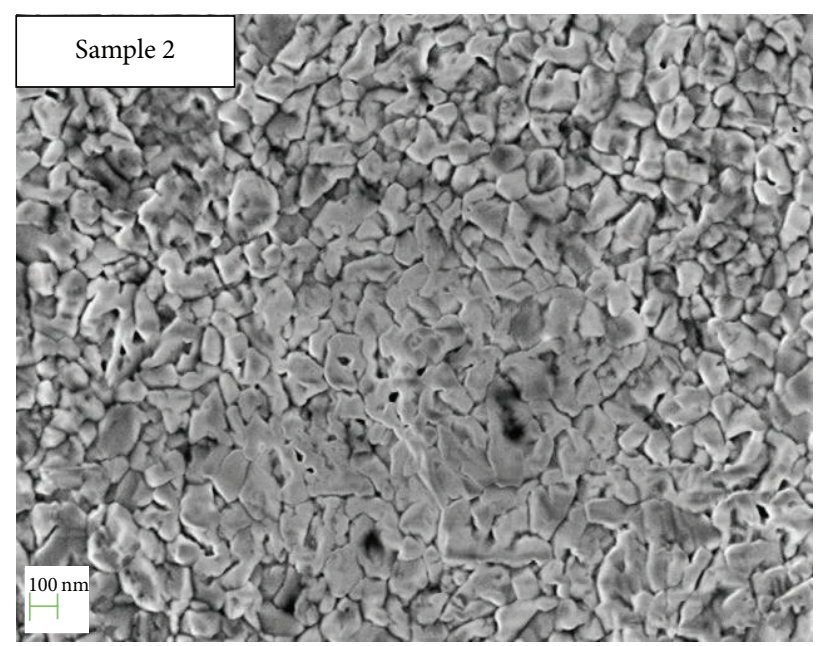

(b)

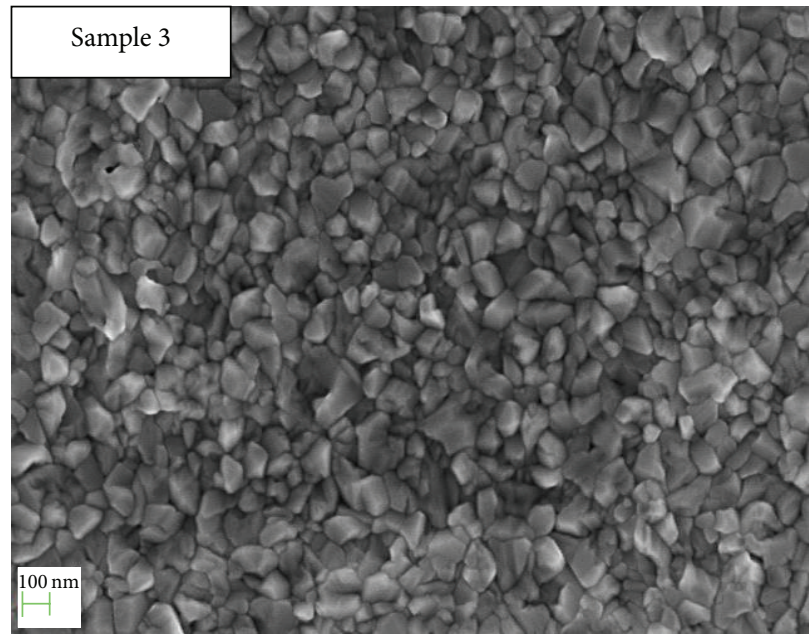

(c)

FIGURE 2: FESEM micrographs of cuprous oxide thin films with irregular grain shape.

The UV-Vis spectra of different $\mathrm{Cu}_{2} \mathrm{O}$ samples are shown in Figure 3. The absorbance of samples may be influenced by grain size, thickness, shape, and the area of $\mathrm{Cu}_{2} \mathrm{O}$ films covered onto ITO coated glass. The films must totally cover the ITO coated glass. The highest absorbance at wavelength of $600-700 \mathrm{~nm}$ obtained for sample 2 is due to its maximum thickness and smallest grain size amongst other samples. This behavior agrees well with the earlier results published by Oral et al. [11]. There is a possibility of increasing of absorbance caused by scattering at grain size as reported by Ray [7]. The absorbance of sample 2 and sample 3 shows the same trend and the absorbance can be improved by increasing the thickness of films.

The addition of polyethylene glycol will produce crack free films with high optical absorbance [5]. Since the polyethylene glycol additive can avoid the particle aggregation occurring in the sol-gel solution, sample 2 with polyethylene glycol has fine crystalline grain $(83 \mathrm{~nm})$ and thus decreases scattering at crystalline boundary. The absorption coefficient, $\alpha$, of the $\mathrm{Cu}_{2} \mathrm{O}$ film is related to the photon energy $h v$ [7]. Consider

$$
(\alpha h v)=\left(h v-E_{g}\right)^{1 / 2}
$$

where $h v$ is the photon energy and $E_{g}$ is the energy gap. These energy gaps are calculated from the intercept of straight line on the photon energy $(h v)$ of $(\alpha h v)^{2}$ versus $(h v)$ plot and the values are listed in Table 1. The energy gap for these films was calculated to be in the range of $1.75-2.0 \mathrm{eV}$ and was found to be influenced by film thickness and also the optical absorbance. The addition of polyethylene glycol produced the thickest film with high energy gap and high optical absorbance.

The $\mathrm{Cu}_{2} \mathrm{O}$ thin films were used as working electrodes in PESC of ITO/ $\mathrm{Cu}_{2} \mathrm{O} / \mathrm{PVC}-\mathrm{LiClO}_{4} / \mathrm{aluminum}$. The layer of $\mathrm{PESC}$ of $\mathrm{ITO} / \mathrm{Cu}_{2} \mathrm{O} / \mathrm{PVC}-\mathrm{LiClO}_{4} /$ aluminum was shown in Figure 4. Most of PESC reported used an aqueous solution 


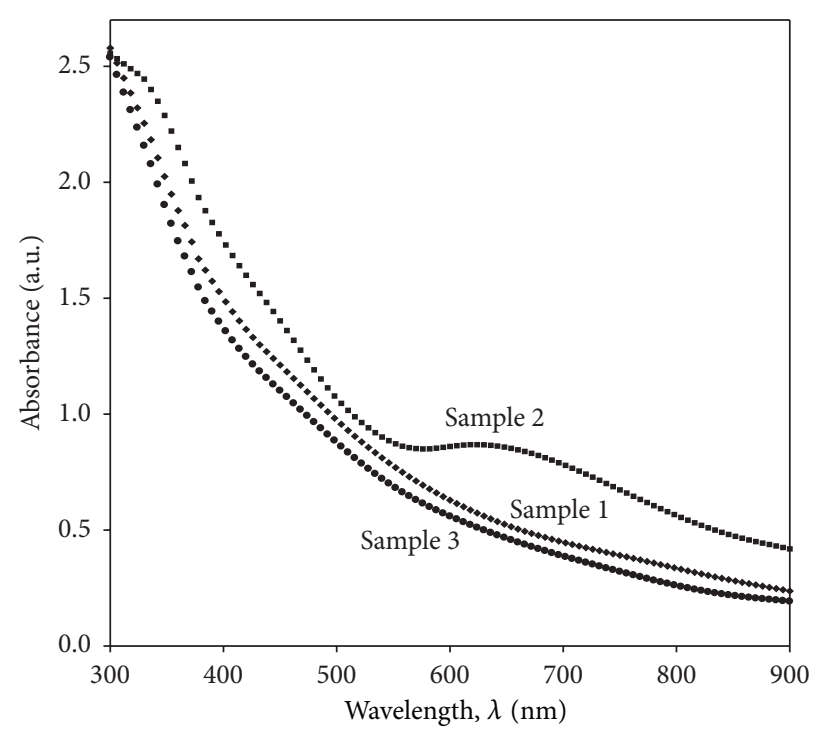

FIGURE 3: The absorbance versus wavelength for three samples with different additives.

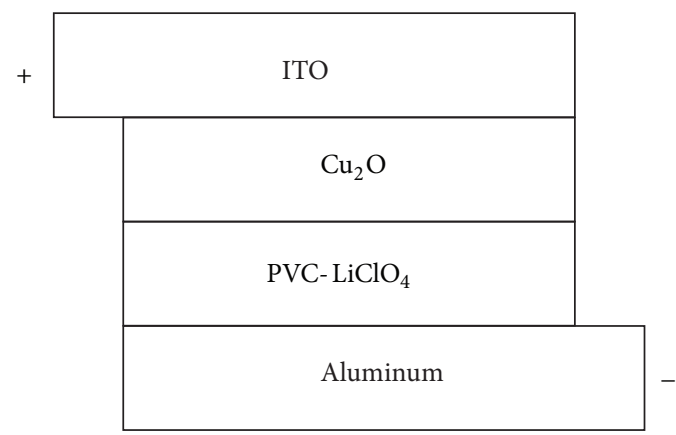

FIGURE 4: Layer of PESC of ITO/Cu $\mathrm{Cu}_{2} \mathrm{O} / \mathrm{PVC}-\mathrm{LiClO}_{4} /$ aluminum.

of $\mathrm{NaOH}$ as an electrolyte. For PESC of ITO/ $\mathrm{Cu}_{2} \mathrm{O} / \mathrm{PVC}$ $\mathrm{LiClO}_{4}$ /aluminum, the solid polymer electrolyte of PVC$\mathrm{LiClO}_{4}$ was used as an electrolyte. The total cell active area was $1.5 \mathrm{~cm}^{2}$. Figure 5 shows current-voltage $(I-V)$ characteristics of the PESC, under dark and light illumination. The $I-V$ characteristic of sample 1 was much different from that of sample 2 and sample 3 due to absence of the additive solutions during its preparation. Sample 2 (sample with polyethylene glycol) and sample 3 (sample with ethylene glycol) have an improvement of $I-V$ characteristic because of the additive. This is the first reported demonstration of photoresponse from a deposited $\mathrm{Cu}_{2} \mathrm{O}$ thin film of $\mathrm{ITO} / \mathrm{Cu}_{2} \mathrm{O} / \mathrm{PVC}-\mathrm{LiClO}_{4} /$ aluminum. Open circuit voltages $\left(V_{\mathrm{oc}}\right)$ and short circuit currents density $\left(J_{\mathrm{sc}}\right)$ of ITO/ $\mathrm{Cu}_{2} \mathrm{O} / \mathrm{PVC}-\mathrm{LiClO}_{4}$ /aluminum PESC were measured under light illumination of $100 \mathrm{~mW} / \mathrm{cm}^{2}$ and shown in Table 2. The best $J_{\mathrm{sc}}$ and $V_{\mathrm{oc}}$ obtained at $100 \mathrm{~mW} \mathrm{~cm}^{-2}$ were $3.2 \times 10^{-11} \mathrm{~mA} / \mathrm{cm}^{2}$ and $0.092 \mathrm{~V}$, respectively, for sample 2 which was the thickest film and absorbed more energy from light. From the results shown in Table 2, it was found that $J_{\text {sc }}$ obtained from this device is low. The ITO/ $\mathrm{Cu}_{2} \mathrm{O} / \mathrm{PVC}$ $\mathrm{LiClO}_{4}$ /aluminum current could be improved by depositing an organic dye onto the $\mathrm{Cu}_{2} \mathrm{O}$ films [18-20] as light sensitizer.
TABLE 2: Value of $J_{\text {sc }}$ and $V_{\text {oc }}$ for PESC of $\mathrm{ITO} / \mathrm{Cu}_{2} \mathrm{O} / \mathrm{PVC}$ $\mathrm{LiClO}_{4} /$ aluminium under light illumination of $100 \mathrm{~mW} / \mathrm{cm}^{2}$.

\begin{tabular}{lcc}
\hline Photoelectrochemical solar cell (PESC) & $\begin{array}{c}J_{\text {sc }} \\
\left(\mathrm{mA} / \mathrm{cm}^{2}\right)\end{array}$ & $V_{\text {oc }}(V)$ \\
\hline Sample 1 & $1.9 \times 10^{-11}$ & 0.090 \\
Sample 2 & $3.2 \times 10^{-11}$ & 0.092 \\
Sample 3 & $1.0 \times 10^{-11}$ & 0.080 \\
\hline
\end{tabular}

This material will absorb a larger quantity of light in the visible region to excite more electrons from its molecule, so that it can be directly sent to the conduction band of $\mathrm{Cu}_{2} \mathrm{O}$ film upon illumination. Further studies are needed on ionic conductivity of the solid polymer electrolyte of $\mathrm{PVC}-\mathrm{LiClO}_{4}$, surface morphology of $\mathrm{Cu}_{2} \mathrm{O}$ and aluminum films, light intensity, and temperature which influence the performance of the cells.

\section{Conclusions}

The $\mathrm{Cu}_{2} \mathrm{O}$ thin films were successfully grown onto ITO substrates by sol-gel spin coating with different additives and 


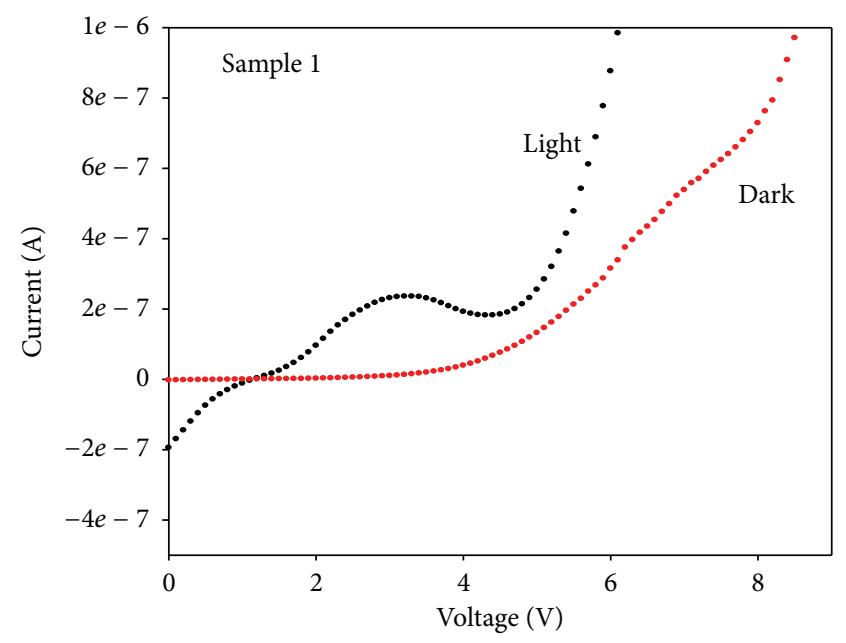

(a)

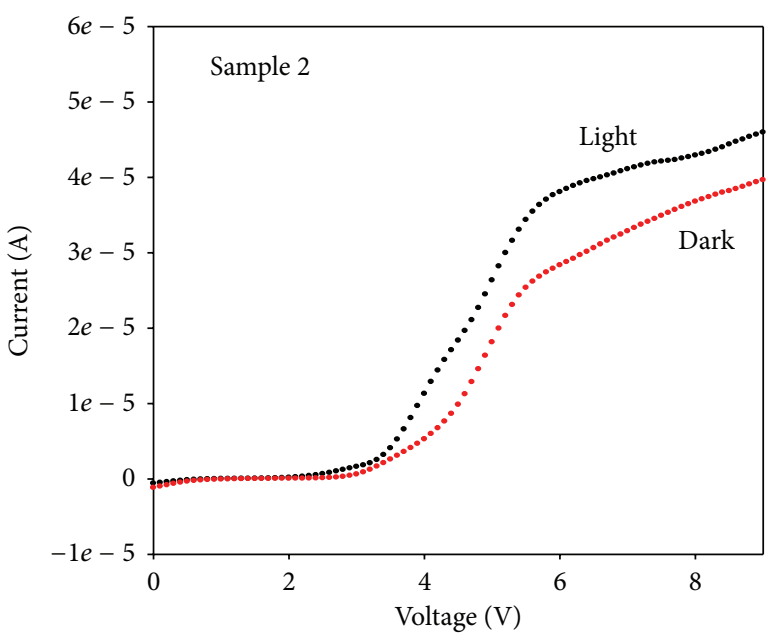

(b)

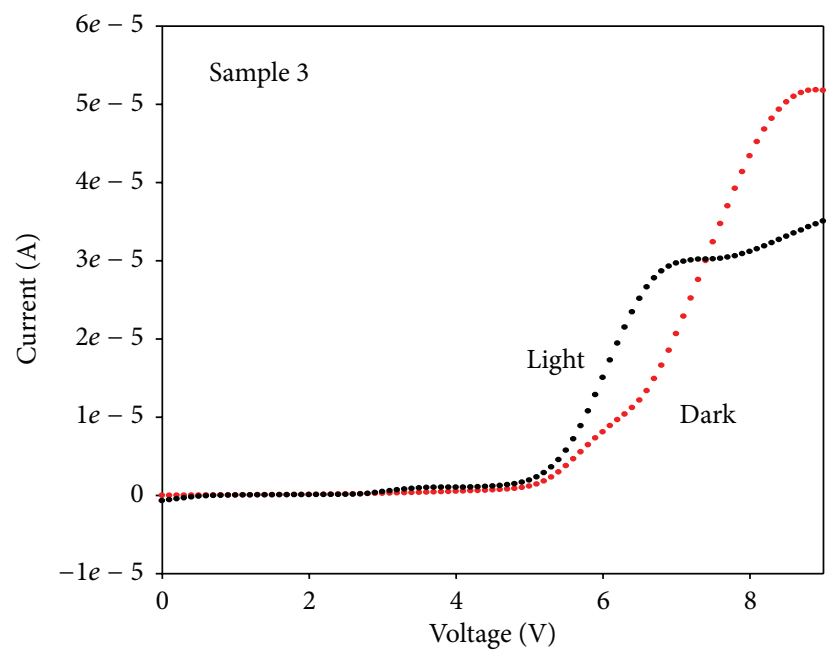

(c)

FIGURE 5: Current-voltage $(I-V)$ characteristics of the PESC of ITO/ $\mathrm{Cu}_{2} \mathrm{O} / \mathrm{PVC}-\mathrm{LiClO}_{4} /$ aluminum under dark and light illumination.

annealed at $350^{\circ} \mathrm{C}$ in $5 \% \mathrm{H}_{2}+95 \% \mathrm{~N}_{2}$ atmosphere. Various properties of $\mathrm{Cu}_{2} \mathrm{O}$ thin films have been characterized. The addition of polyethylene glycol to the parent solution can enhance various properties of the films, such as increasing optical absorbance, energy gap, and the thickness of films. These results indicate that the $\mathrm{Cu}_{2} \mathrm{O}$ thin film prepared by sol-gel spin coating technique using polyethylene glycol and ethylene glycol can be used for photoelectrochemical solar cell (PESC).

\section{Conflict of Interests}

The authors declare that there is no conflict of interests regarding the publication of this paper.

\section{Acknowledgment}

The authors gratefully acknowledge the financial support by MOSTI, through Science Fund Grant no. 03-01-02-SF0211.

\section{References}

[1] V. Georgieva and A. Tanusevski, "Optical band gap energy determination of thin films of cuprous oxide," in Proceedings of the 5th General Conference of the Balkan Physical Union, pp. 2311-2315, August 2003.

[2] H. Tanaka, T. Shimakawa, T. Miyata, H. Sato, and T. Minami, "Effect of AZO film deposition conditions on the photovoltaic properties of $\mathrm{AZO}-\mathrm{Cu}_{2} \mathrm{O}$ heterojunctions," Applied Surface Science, vol. 244, no. 1-4, pp. 568-572, 2005.

[3] S. Ishizuka, S. Kato, T. Maruyama, and K. Akimoto, "Nitrogen doping into $\mathrm{Cu}_{2} \mathrm{O}$ thin films deposited by reactive radiofrequency magnetron sputtering," Japanese Journal of Applied Physics, Part 1: Regular Papers and Short Notes and Review Papers, vol. 40, no. 4, pp. 2765-2768, 2001.

[4] S. Ghosh, D. K. Avasthi, P. Shah et al., "Deposition of thin films of different oxides of copper by RF reactive sputtering and their characterization," Vacuum, vol. 57, no. 4, pp. 377-385, 2000.

[5] K. P. Muthe, J. C. Vyas, S. N. Narang et al., "A study of the $\mathrm{CuO}$ phase formation during thin film deposition by molecular beam epitaxy," Thin Solid Films, vol. 324, no. 1-2, pp. 37-43, 1998. 
[6] M. T. S. Nair, L. Guerrero, O. L. Arenas, and P. K. Nair, "Chemically deposited copper oxide thin films: structural, optical and electrical characteristics," Applied Surface Science, vol. 150, no. 1, pp. 143-151, 1999.

[7] S. C. Ray, "Preparation of copper oxide thin film by the solgel-like dip technique and study of their structural and optical properties," Solar Energy Materials and Solar Cells, vol. 68, no. 3-4, pp. 307-312, 2001.

[8] K. Nakaoka and K. Ogura, "Electrochemical preparation of ptype cupric and cuprous oxides on platinum and gold substrates from copper(II) solutions with various amino acids," Journal of the Electrochemical Society, vol. 149, no. 11, pp. C579-C585, 2002.

[9] A. K. Mukhopadhyay, A. K. Chakraborty, A. P. Chatterjee, and S. K. Lahiri, "Galvanostatic deposition and electrical characterization of cuprous oxide thin films," Thin Solid Films, vol. 209, no. 1, pp. 92-96, 1992.

[10] L. Armelao, D. Barreca, M. Bertapelle, G. Bottaro, C. Sada, and E. Tondello, "A sol-gel approach to nanophasic copper oxide thin films," Thin Solid Films, vol. 442, no. 1-2, pp. 48-52, 2003.

[11] A. Y. Oral, E. Menşur, M. H. Aslan, and E. Başaran, "The preparation of copper(II) oxide thin films and the study of their microstructures and optical properties," Materials Chemistry and Physics, vol. 83, no. 1, pp. 140-144, 2004.

[12] K. Kajihara and T. Yao, "Macroporous morphology of the titania films prepared by a sol-gel dip-coating method from the system containing poly(ethylene glycol). IV. General principle of morphology formation and effect of heat treatment," Journal of Sol-Gel Science and Technology, vol. 17, no. 2, pp. 173-184, 2000.

[13] A. Matsuda, T. Kanzaki, K. Tadanaga, M. Tatsumisago, and T. Minami, "Proton conductivities of sol-gel derived phosphosilicate gels in medium temperature range with low humidity," Solid State Ionics, vol. 154-155, pp. 687-692, 2002.

[14] L. Huang, F. Peng, H. Yu, and H. Wang, "Synthesis of $\mathrm{Cu}_{2} \mathrm{O}$ nanoboxes, nanocubes and nanospheres by polyol process and their adsorption characteristic," Materials Research Bulletin, vol. 43, no. 11, pp. 3047-3053, 2008.

[15] I. R. Collins and S. E. Taylor, "Non-aqueous thermal decomposition route to colloidal inorganic oxides," Journal of Materials Chemistry, vol. 2, pp. 1277-1281, 1992.

[16] D. Jezequel, J. Guenot, N. Jouini, and F. Fiévet, "Submicrometer zinc oxide particles: elaboration in polyol medium and morphological characteristics," Journal of Materials Research, vol. 10, pp. 77-83, 1995.

[17] L. Poul, N. Jouini, and F. Fievet, "Layered hydroxide metal acetates (metalzzinc, cobalt, and nickel): elaboration via hydrolysis in polyol medium and comparative study," Chemistry of Materials, vol. 12, pp. 3123-3132, 2000.

[18] P. M. Sirimanne, T. Shirata, L. Damodare, Y. Hayashi, T. Soga, and T. Jimbo, "An approach for utilization of organic polymer as a sensitizer in solid-state cells," Solar Energy Materials and Solar Cells, vol. 77, pp. 15-24, 2003.

[19] K. Imoto, K. Takahashi, T. Yamaguchi et al., "High-performance carbon counter electrode for dye-sensitized solar cells," Solar Energy Materials and Solar Cells, vol. 79, pp. 459-469, 2003.

[20] S. Ito, T. Kitamura, Y. Wada, and S. Yanagida, "Facile fabrication of mesoporous $\mathrm{TiO}_{2}$ electrodes for dye solar cells: chemical modification and repetitive coating," Solar Energy Materials and Solar Cells, vol. 76, pp. 3-13, 2003. 

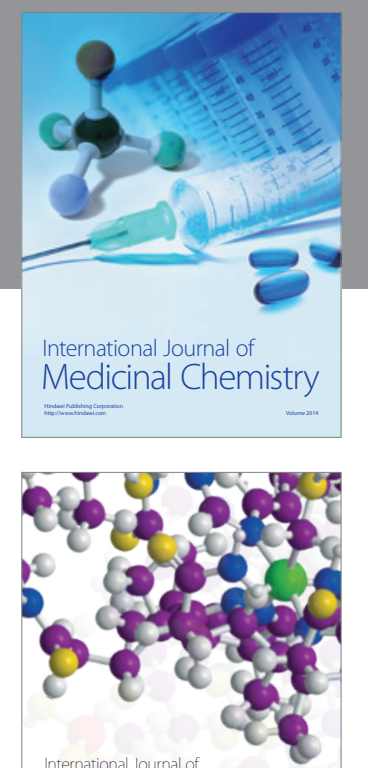

\section{Carbohydrate} Chemistry

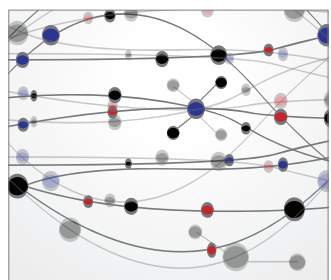

The Scientific World Journal
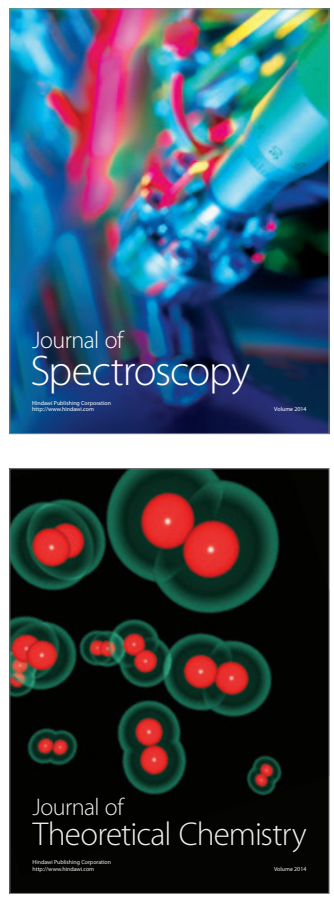
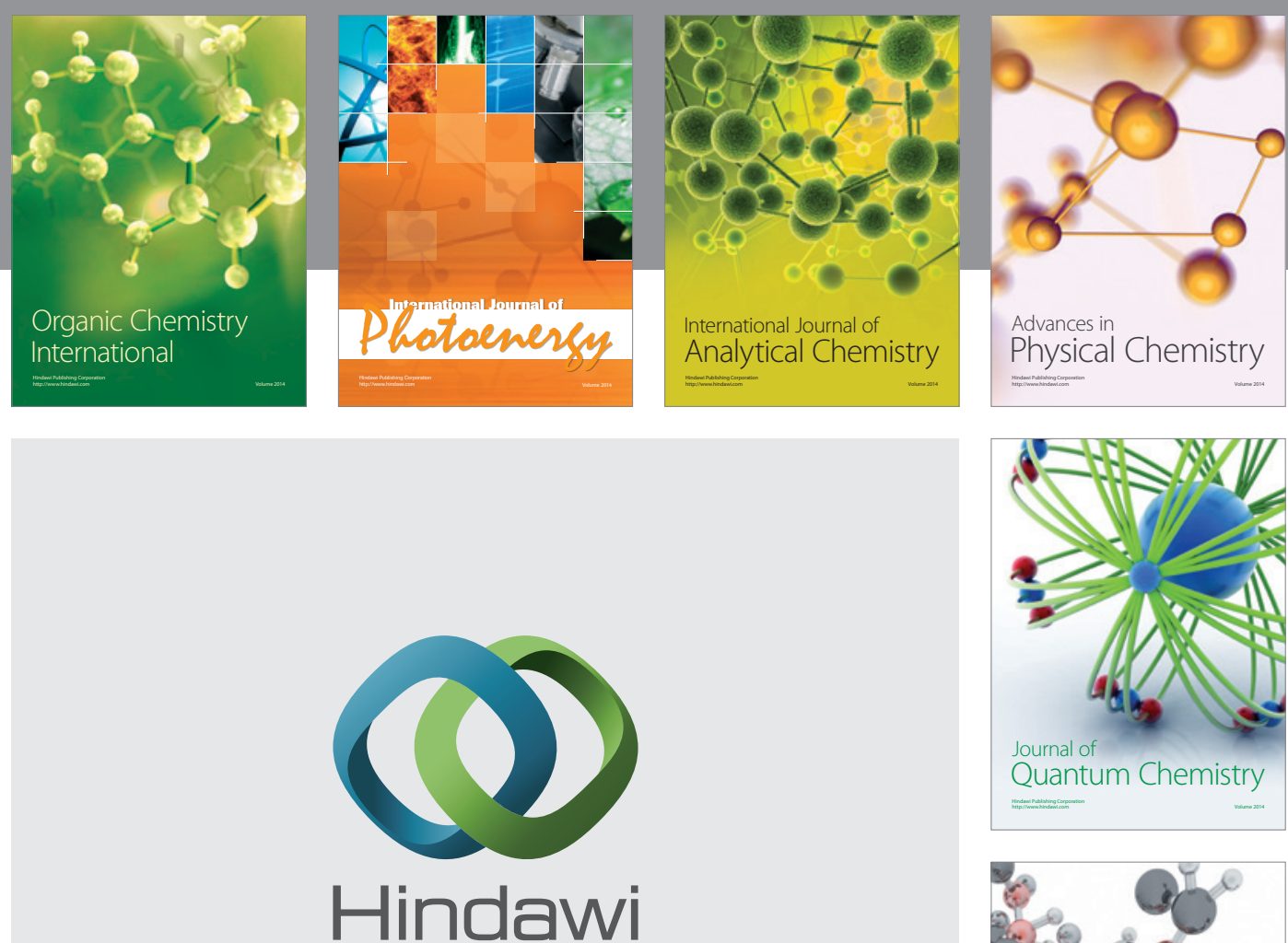

Submit your manuscripts at

http://www.hindawi.com

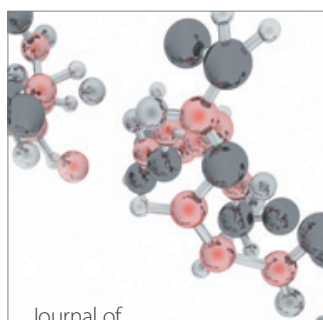

Analytical Methods

in Chemistry

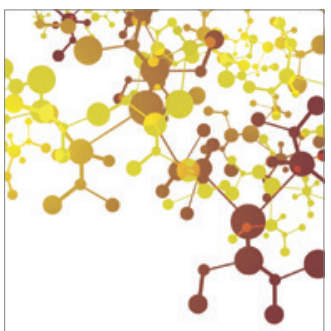

Journal of

Applied Chemistry

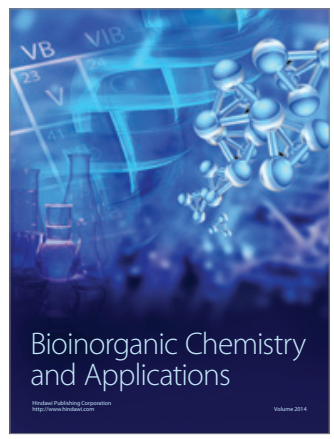

Inorganic Chemistry
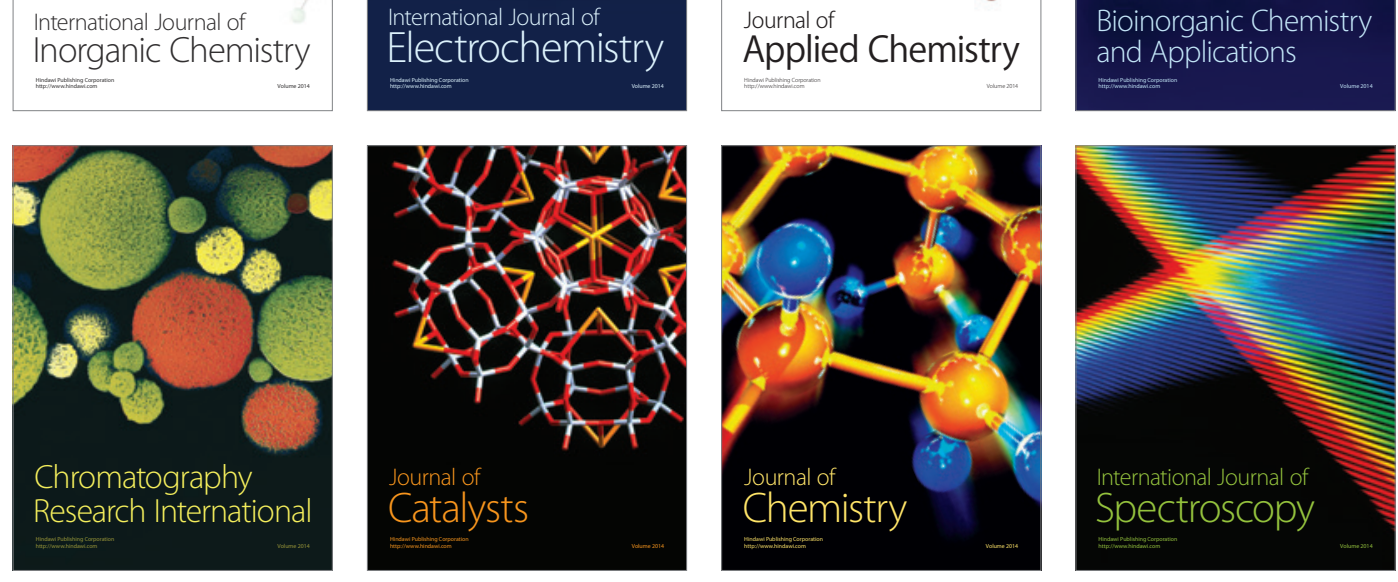